\title{
Zimmermannella bifida
}

National Cancer Institute

\section{Source}

National Cancer Institute. Zimmermannella bifida. NCI Thesaurus. Code C86868.

A species of aerobic, Gram positive, rod shaped bacteria assigned to the phylum

Actinobacteria. This species is catalase and alkaline phosphatase positive, oxidase,

gelatinase and urease negative, and may be able to ferment ribose and rhamnose. $Z$.

bifidus is not a known human pathogen. 